\title{
WHAT VIEW OF THE ATONEMENT IS OF MOST VALUE FOR THE DEVOTIONAL LIFE.
}

BY PROF. I. S. GUBELMAN, D.D., ROCHESTER, N. Y.

In considering the question here proposed: What view of the atonement is of most value for the devotional life, it would be proper to answer: That view which is most in accordance with Scripture testimony. We may assume that Biblical truth concerning this important subject must be designed for and adapted to the production of the highest results in regard to the devotional life. This would fully justify us in attempting the solution of this question by an examination of Scripture testimony concerning the nature of the atonement.

But while such a procedure would be justifiable and might be considered to be conclusive it may nevertheless be well for us to approach this subject in a somewhat different manner and to inquire into the relation which different views concerning the atonement bear to the devotional life. The result of this inquiry will aid us in deciding what view can best lay claim to a scriptural character, and what view is best attested by Christian experience. We may take it for granted that the view which is of highest devotional value is most likely to be the correct Biblical view.

It will not, I presume, be expected of me, that within the very narrow limits to which I find myself restricted I should attempt to enter upon a minute examination of past and present views of the atonement, or that $I$ should attempt to give a summary even of the history of opinion regarding this topic. I must content myself by stating briefly the contents of the view which I hold to be of the highest devotional value and by giving some reasons which lead me to accord to it this devotional excellence.

The view to which $I$ refer is that according to which there is a necessary and unique relation between Christ's death and man's pardon; the view according to which Christ's death is a sin offering of infinite value; or, to speak in Biblical language 
the view which holds that God has set him forth to be a propitiation, through faith, by his blood (Rom. 3:25) that God made him who knew no sin to be sin in our behalf ( 2 Cor. $5: 21$ ), that is, that he took our place as our substitute in suffering on account of our guilt; that he is the propitiation $i \lambda a \sigma \mu \sigma^{\prime}$ for our sins, and not for ours only, but also for the whole world. (1 John $2: 2$.)

According to this view the necessity of this ricarious death does not consist in any unwillingness on God's part to pardon the sinners, but in the ethical character of God which demands that his infinite love to man be manifested and exercised in a manner not in conflict with his infinite holiness, but in perfect harmony with it, and in the fact that only such a manifestation of God's love as is given in Christ's vicarious death, can quiet the accusations of an awakened conscience and effectively influence man's heart and disposition.

of course a fuller statement of this view would involve the reference to questions such as these: how far does this substitution involve an equality of penalty; what gives to Christ's death this unique significance and value; how may the ethical propriety of such a substitution be shown; but for our present purpose we may confine ourselves to this main statement.

We ask now for the reasons why this view may be held to be of the highest value for the devotional life.

And here we may first inquire as to what is meant by the devotional life. I take it to mean that form of man's soul-life in which man's consciousness of his relation to God finds its expression. A certain kind and degree of that devotional life may be affirmed as belonging to the adherents of any religious system; we ask for that form and degree of it in which man's consciousness and enjoyment of his relation to God finds its highest, its most complete, expression.

If now we will consider some of the essential elements which enter into this highest form of the devotional life, that consideration will aid us in testing the devotional value of the view concerning the atonement which is here presented.

And first, we shall all agree, I suppose, that true humility 
must characterize the true devotional life. If God is an infinite being and man is finite; if God is a being of absolute holiness and man is very imperfect and sinful, it behooves man to draw nigh unto God in lowliness of heart and deep contrition.

Now what view of the atonement will be best suited to produce and strengthen in the soul this humble disposition, this contrition? Will it not be that view which presents to man in the death of Christ the reality and magnitude of human sin, a sin which demanded such a sacrifice to render its pardon possible in harmony with God's holiness? Will it not be that view of Christ's death which reveals most fully God's infinite aversion to sin, while at the same time it reveals God's wonderful mercy? Can there be a fuller $\ddot{e} \nu \delta \epsilon \iota \xi \iota$ as Paul terms it (Rom. 3:25, 26), that is a fuller manifestation and declaration of God's justice in its opposition to sin, a fuller revelation of God's judgment against it than that which is given on Calvary? Here God condemns sin in the flesh (Rom. 8:3) and whoever looks to the cross with the conviction that there the great sinbearer suffered and died, cannot but be led to draw nigh unto God in deep humility.

But deep humility and contrition is only one of the elements which constitute the highest devotional life. If it remained alone it would be the humility of despair and true fellowship with God would be impossible. Confidence, trust in God is equally essential. I must be enabled to trust in God as my reconciled Father, if $I$ am to enjoy the highest form of the devotional life; I must be firmly convinced that notwithstanding my sin, God loves me, is anxious to pardon me; in a word I must be enabled to trust in God's infinite love.

Now what view of the atonement will be most likely to produce this essential element of trust, this reliance upon God's love? It is not so easy and natural for a man who is a sinner to believe in God's love, as it is sometimes claimed to be. The matter is not so selfevident. The heathen at least did not seem to find their way to this truth. God's manifestations in nature may frequently leave us in doubt regarding it. It may be com. paratively easy for a self-righteous man, who has never been 
deeply conscious of his guilt before God, who has never been deeply humbled on account of sin; it may be comparatively easy for auch a person to speak almost flippantly concerning the Fatherhood of God, concerning God's universal love; he has unconsciously borrowed this truth from Christianity and he appropriates it without considering in the least how it can be held in unison with the truth concerning man's guilt and God's holiness and justice; he simply cuts the guardian knot by ignoring God's justice or by identifying it with his love to man. But to the sinner whose conscience is aroused by a sense of sin and deserved punishment this trusting in the love of God is not so easy; for him the mere assertion that God loves man will not suffice, it will not quiet his accusing conscience, nor give him peace with God. Such a soul needs some sure pledge that God can and does indeed love even the most sinful, some explanation how that can be, how a Holy God who looks upon sin with infinite aversion can at the same time freely pardon the guilty sinner.

And where, we may boldly ask, can the awakened conscience obtain a surer pledge of God's love to sinful man and a more satisfying explanation and vindication of that faith than in the interpretation of Christ's death which shows how in the death of Christ God's love is manifested in a manner which does not abrogate but exalt God's justice?

True, it is claimed by some that the cross serves as a demonstration of God's pardoning love to sinners and as an interpretation of God's heart of affection simply, and that there existed no inherent necessity for such a sacrifice in God's holiness and justice. But are we not compelled to say that for God to express his love in a manner which would ignore or deny his holiness and justice, must be for a Holy God an ethical impossibility? And how could a death that were not really needed for our salvation be as great a manifestation of God's love, as a death which shows God's willingness to exercise his mercy even at such a cost? To quote the pertinent words of a recent writer on this topic: "The simplest hearer feels that there is something irrational in saying that the death of Christ is a grent proof of God's love to the sinful, unless 
there is shown at the same time a rational connection between that death and the responsibilities which sin involves, and from which that death delivers."

We are justifled then in saying that this view of the atone ment gives to the death of Christ the highest significance as a revelation of God's pardoning love and thus enables the soul, when its presentation is accompanied by the influence of the Spirit, to trust confidently in that love for pardon and salvation and to live from henceforth a life of filial trust and confidence in God. If then to trust in God, to rely upon and rest in his love is an essential element in the devotional life, this view of the atonement most surely produces and cherishes this element.

It is hardly necessary to remind ourselves that love to God is essential for the highest devotional life. Now what is the genesis of this love, upon what does it feed? It certainly cannot thrive where servile fear prevails, it is the necessary product of that confidence in God's love which fills the heart of the believer.

That view then concerning Christ's death which produces the deepest conviction of sin, but at the same time the deepest conviction concerning the magnitude of God's wonderful love to the sinner is best adapted to call forth and to cherish in the soul the deepest response of reciprocal love; it will prompt believers to exclaim: "We love, because he first loved us." (I John 4:19).

If then, as we have endeavored to point out, this view which holds the vicarious significance of Christ's atonement is best adapted to fill the troubled soul with confidence in God, with assurance concerning his pardoning mercy it is equally well adapted to make our devotional life one of intense love to God.

And this love, thus produced within us, will certainly be the main-spring for holy living, for a life of cheerful obedience to God. It has been well said by Augustine: "Amorordo virtutis." Love is the law of virtue; love to God produces Christian virtue in that it capacitates the soul for willing obedience and in that it has every individual virtue in its train. Love to 
God secures the fulfillment of Christian duty; it not only prompts to duty but it transfigures duty into privilege. And this love will certainly find its expression in the joyful worship of gratitude.

I can only add that the devotional life produced by this view will necessarily be one which makes Christ as our Savior in. estimably precious to the soul, one which enables the believer to say truly: "The life which I now live in the flesh I live by faith, the faith which is in the Son of God, who loved me and gave himself up for me."

And as to the influence of the Holy Spirit upon which the manifestation of the fullest and truest devotional life absolutely depends, it seems evident that this activity of the Spirit must necessarily stand in an intimate connection with that conception of the atonement which fully reveals God's holiness and which at the same time presents the death of Christ as the highest manifestation of God's love to mankind. As the apostle says: "The love of God hath been shed abroad in our hearts." That is, this precious truth concerning God's love manifested in Christ has been consciously appropriated in the heart--"through the Holy Ghost which was given unto as." (Romans 5:5).

It would not be difficult to show how the actual experience of thousands upon thousands of true believers corroborates and attests the fact concerning the devotiona! value of this conception in relation to the atonement. I think that an appeal to Christian experience would fully bear me out in this claim.

If now the elements mentioned are indeed the most essential elements which constitute the highest devotional life, we may fairly challenge any one to present another view of the atonement of equal or higher devotional value. We hold this view not simply on the ground of its devotional significance, but because we are led to believe that it can be fully substantiated by Scripture testimony. But the fact of its devotional value, of the blessed results flowing from its acceptance, wherever it is truly arcepted under the influence of the divine Spirit, is to us a strong attestation of its truth. 
The question which we have thus endeavored briefly to consider is by no means a mere theoretical or speculative question, it is a question which stands in intimate relation to our own religious and moral welfare and to the welfare of those to whom we preach. Man needs the removal of guilt, the as. surance of God's pardon, he needs an influence, a power, which will not only pacify an accusing conscience but which will also fill the heart with flial confidence and thrill the soul with that intensity of affection which will manifest itself in willing obedience and in joyful grateful devotion. Can this view of the atonement do this? Does it do it where the Spirit uses it and accompanies it? Does this view prove itself to be that 'word of the cross' which is unto us who are being saved the power of God? (1 Cor. 1:18). If so, it must be the gospel, and it becomes our duty and our precious privilege to preach it. 